\title{
Optimization of Hybrid Energy Systems for Rural Electrification
}

\author{
Ekpo, Andifiok Aloysius \\ Department of Electrical/Electronic \\ University of Port Harcourt \\ Port Harcourt, Nigeria.
}

\author{
Dr Nelson Ogbogu \\ Department of Electrical/Electronic \\ University of Port Harcourt \\ Port Harcourt, Nigeria.
}

\begin{abstract}
This study is an optimization of hybrid energy system in Nigeria, the energy requirement of Ikot Inyang rural community is satisfied after carrying out the design and simulation of different variables, the optimal systems were a system that consisted of 5 wind turbines, solar models and a diesel generator as energy sources. Ikot Inyang is a rural community located in Akwa Ibom state, South-South Nigeria, the community is connected to the national electricity network (grid) but the power supply is rarely consistent. The load estimate analysis showed that Ikot Inyang had peak load $58.62 \mathrm{~kW}$ and peak energy demand per day as $670.65 \mathrm{kWh}$. Eight (8) different design plans were considered and simulations were carried out using HOMER software. Several factors were used to determine the most optimal system, which includes the Net Present Cost, Levelized Cost of Energy, Renewable Fraction and system emissions. This was carried out for the 25 years project life time. The design plans were made of stand-alone systems as well as combination of many generating sources with battery included in some systems, various simulations were carried out. HOMER Presented the most technical and economical solution to meet the load demand at the least Net Present Cost, least Levelized Cost of Energy and allowable Renewable fraction. The most optimal solution for Ikot Inyang involved a combination of a 50Kw diesel generator, 5 Bergey Excel 10 wind turbine, 134kW solar model, 204 strings of Hoppecke 12 OPzS 1500 battery and 2 Leonics MTP-413F 25kW converter. The dispatch method used for this system was the Load Following dispatch method. This method produced at least Net Present Cost of \$1.7M (N349.36M), Levelized Cost of Energy of \$0.228 (N74.74), considerably high Renewable Fraction of $84.7 \%$, When this result was compared with a diesel generator only system, it showed $77.2 \%$ reduction in the diesel saving fuel cost. Comparison with a design plan consisting of diesel generator only showed that $202,155 \mathrm{~kg}$ of carbon dioxide is saved per year and $1,262 \mathrm{~kg}$ of carbon monoxide is saved per year when making use of the most optimal system design.
\end{abstract}

Keywords: HOMER, Renewable Fraction, Levelized Cost of Energy, Net Present Cost, Optimal System Design

\subsection{INTRODUCTION}

Up to two billion people around the world have no accessibility to grid connected electricity most of which are underdeveloped communities (rural area) according to the research carried out by the United Nations Environment Program (UNEP) [1]. The Inaccessibility to electricity in the rural has directly influenced rural population migration and reduction in the workforce in the rural communities which mostly deal with agricultural produce which also contributes significantly to an economy.

In Nigeria, the power generated and supplied to national grid is still very small compared to the country's load demand, and the geography of some rural communities makes it difficult for them to have access to the nation's grid supply, hence the need for off-grid power generation becomes inevitable [2]. As started by [3], over 100 local government areas in Nigeria are still not connected to the nation's grid system, hence the need for off-grid electrification cannot be over emphasized.

In the last decade, rural electrification in Nigeria with renewable energy with off-grid connection has become a suitable alternative for communities where connection to the grid is neither is not present or economically viable [4].

Harsh terrains and isolation of rural communities are among the various factors are responsible for the poor distribution of electrical resources [5]. Nevertheless, the main reason for poor distribution is that it is not economically feasible, it is too expensive to expand the grid over long distances just to supply a small number of people with electricity in a rural community [5]. Because of this, the only viable option to consider that is economically feasible, reliable and dependable is to make use of Hybrid Energy System (HES). Hybrid Energy System (HES) is very cost friendly and can be utilized where difficult terrains are found and where energy supplied to the grid is limited and insufficient. Hybrid Energy System (HES) is a good alternative for supplying electricity to the rural areas rather than connecting to the national grid where the community is either isolated or situated at a location with a harsh terrain.

Hybrid Energy Systems (HES) is mostly made of a backup generator which supplements the output power for a Solar $\mathrm{PV}$ and wind systems during periods of peak loads and poor resource availability. One of the greatest advantages of Hybrid Energy Systems is the ability for energy sources to complement each other. Here the strengths (merits) of each sources type are used to complement the weaknesses (demerits) of each other [6].

Stand-alone Hybrid Energy Systems incurs less cost and has a higher reliability than single systems either photovoltaic (PV) or wind systems [7]. Also, the installation of PV module to meet load demand at all times, will lead to excessive generation for certain month of increase and 
maximum solar radiation leading to wastage of energy generated for some months.

HOMER (Hybrid Optimization Model for Electrical Renewables) was developed in USA by National Renewable Energy Laboratory, according to (Jose' et al., 2009), this is the software mostly utilized for optimization of Hybrid Energy Systems.

\subsection{REVIEW OF RELATED LITERATURES}

The standard of living of any economy depends massively on the accessibility to sustainable, reliable and affordable energy supply. For the growth, development and stability of the economy of any nation, sufficient and consistent energy supply is a necessity. A nation cannot beyond a certain level without access to an energy source [8].

United Nations Environmental Program (UNEP) conducted a survey, the survey revealed that close to two billion people around the globe have no access to electricity from the nation's grid system and the people in this group are people are mostly residents of rural communities [8],[9].

Population rise which leads to proliferate socio-economic activities which in turn increased energy demand, this continuously increases energy demand must be met by continuously increasing energy supply. The appropriate measuring yardstick for sustainable socio-economic growth is electricity supply. According to [8], Close to forty percent of the population of Nigeria are not connected to the national grid system, this are mostly people living in the rural communities of Nigeria and they rely on biomass (wood, dung etc), batteries and at other times self-generation of electricity.

According to [10], the supply of grid-based electricity to some rural and remote communities fronts some serious economic challenges, especially when the community has a difficult geographical terrain and is scantily populated. In Nigeria, due to insufficient and inconsistent supply, preference of supply is given to commercially productive areas and areas economically beneficial to the power company, this is mostly cities and urban areas because they are densely populated. For some rural areas in Nigeria, although connected to the nation's grid system, due to insufficient energy supply which cannot match load demand, rural and remote communities are mostly load-shedded making to complement grid supply with self-powered generation.

[11], stated that globally more than 1.7 billion people live independent of the grid-based electricity supply. This doesn't include those connected to the grid but with epileptic supply of electric energy. World bank energy facts as quoted by [2], approximately 1.2 billion people globally which amounts to $20 \%$ of the population globally are without access to electricity supply and approximately all the people in this class are residents of developing countries. In the past India was among this group, but excluded themselves because they restructured their interconnected system to not only be grid dependent but they developed distributed energy generation which included standalone, mini and micro power plants.

\subsection{Rural Electrification and Hybrid Renewable Energy System}

Population growth, technological advancements and improvement in the growth in the standard of living has led to global rise in energy consumption and demand. Due to this fact, many rural and remote communities are deprived of electricity as they are not seen as priority and because electricity supply cannot match the teeming energy demand. The answer to this issue is to increase the amount of electricity generated and supplied and to reduce transmission losses. But most of world electricity plants are power by fossil fuels. Fossil fuels are exhaustible and it cannot meet future electricity needs due to their negative influence on the environment. Making use of renewable resources not as an immediate replacement but as alternatives and supplements to fossil fuels is rapidly becoming the most efficient method of electricity generation. When renewable is generated individually and in small unit, it becomes a very costly option and it comes with so many technically difficulties due to intermittent availability of renewable resources and their unpredictable nature. The solution to this problem is the utilization of Hybrid Renewable Energy Systems [12].

Hybrid Renewable Energy Systems is the merging of renewable, conventional energy sources and different kinds of energy storage to meet both or either grid connect and standalone loads. Hybrid Renewable Energy Systems are mostly utilized in rural areas and secluded communities.

When this is method is used, the uncertain and unpredictable nature of renewable resources, the demerits of traditional resources all supplement for each other. When the electricity production of the renewable energy sources is not large enough to meet the required load, the remaining load is meet by a back-up energy sources, either from the storage or from the conventional energy sources. Also, when the renewable sources produce more than required electric energy, the required energy feeds the load and the left over is sent to be stored by the different kinds of storage utilized either battery or pump storage but the most popular and economically available option is the use of battery cells.

The use of Hybrid Renewable Energy Systems is more reliable and efficient that the renewable sources especially in a standalone/off-grid mode. Hybrid Renewable Energy Systems has been implemented in places such as estates, university, factories etc. In this scenario when, during off peak periods when the electricity from the grid is cheapest, the load demand is met by energy from the grid, but at peak periods, electric energy demand is met by Hybrid Renewable Energy sources and the extra energy is either stored by the energy storage systems or sold to the grid [13]. Also, the energy stored in energy sources are utilized to meet extra electricity demand or they are sold for profits into the grid. There are great advantages of Hybrid Renewable Energy Systems which includes; reduced levelized cost of energy, reduction in $\mathrm{CO}_{2}$ emission, protection of the environment by 
cutting down the emission of greenhouse gases, poisonous substance and industrial waste, generation of cheap electricity for rural communities, increased reliability, dependency and efficiency. According to all the above listed advantages meets all the criteria of Sustainable Development which are made of the environmental, social and economic aspects [14].

For design and optimization purposes, many theoretical approaches have been adopted and many simulation and optimization models has been developed and has been discussed in details by [15]. [16], worked on the design and control techniques in order to simulate and optimize a standalone Hybrid Renewable Energy Systems, another optimization tool and techniques were developed for optimal design by [17] and they developed models for the Optimization in microgrids with hybrid energy systems. A critical review on the developments in Hybrid wind/Photovoltaic energy systems with a battery storage system and a converter by [18] and they shared their findings.

There have been other studies carried out on Hybrid Renewable Energy Systems on either grid-connected systems or standalone systems which includes energy management, cost analysis, optimization techniques, software and simulation designs, planning criteria and other design parameters have been reviewed in [19], [20].

Many authors have made use of HOMER in their study and their design of optimal hybrid energy systems. [21] worked on the rural village electrification in South Africa: role of energy efficient in off-grid PV/dg system, in their works the made the relationship between the process of optimization and sizing the various component of a Hybrid Renewable energy systems and the energy efficiency. This investigation was carried out in a rural community in south Africa, covering 30 households. He summarized that the reduction in the operation time of a diesel generator can be cut down by up to $20 \%$, if households made of efficient lamps and energy save appliances which would also lead to the reduction of $\mathrm{CO}_{2}$ emission.

An evaluation of hybrid wind/diesel energy potential in pemanggil island Malaysia, was carried out by [22], they examined the potential energy output of a wind/diesel hybrid with battery storage. They examined extensively the influence of wind speed, penetration, and energy stored in the battery on the cost of energy, annual operational hours of the diesel generator and energy production. An analysis of hybrid wind/fuel cell /battery/ diesel energy system under alaska condition was designed and simulated by [23], they designed was simulated with the aim of reducing the gas emission by $37 \%$ in comparison with the previously existing system.

[24], in their paper on Modelling of solar/diesel/battery hybrid power systems for far-north Cameroon, this was meant for the electrification of domestic households and schools in the rural community in northern Cameroon. [25], worked on assessment of off-shore wind farms in Malaysia, and in their work, they concluded that there was great wind potential if a wind turbine is placed alone the South China sea coast line and optimized accordingly. here their design was made with Vestas V-47 and V-48 wind turbine and hence economic optimization and feasibility studies were performed accordingly. [26], worked on Balancing cost, operation and performance in integrated hydrogen hybrid energy system designed to feed and supply small rural community with electricity. They focused on designing and optimizing a hybrid energy system whose primary sources was hydrogen, this was to enable them to obtain a hydrogen independent system. They also collectively developed an algorithm for determining the correct size of individual system and for the optimizing the system collectively.

Biomass gasifier-based hybrid energy system for rural areas was designed by [27], this incorporated a biomass gasifier plant as one of the energy sources joined with other renewable sources of energy. To determine optimal designs of hybrid energy systems, some factors are considered which includes; load demand, non-linear seasonal variations, sizing and constraints of equipment as well as cost. Making use of HOMER software, [28], worked on the potential of grid connected photovoltaic array in Zimbabwe. Their analysis showed that to make generation of electricity from solar photovoltaic competitive, the electricity market was to increase the tariff of electricity to a minimum of $\$ 0.15 / \mathrm{kWh}$ in specific areas whose minimum daily solar irradiation is at least $5.6 \mathrm{Wh} / \mathrm{m} 2$.

[29], carried out an analysis on the technical and economic assessment of power generation from landfill gas in south Africa, in the investigation he also analyzed the environmental impact of making the hybrid system a standalone system or grid-based system respectively. He came a conclusion that either standalone system or grid-tied systems are both feasible, however that it was cheaper to install a standalone system than a grid-tied system.

In a research work carried out by [30] on the technical and economic analysis of different micropowers in providing network load and optimal selection with real load analysis of a $20 \mathrm{kv} / 400 \mathrm{v}$ station in busher province of Iran, simulations were made based on different hybrid configurations, the objectives were to determine technical and economic feasibility as well as determine their impact on the environment. When considering the most optimal system in terms of cost, technicality as well as environmental impact, solar photovoltaic stood out as the most optimal system.

[31], worked on the Sizing methods for stand-alone hybrid systems based on renewable energies and hydrogen, here he made a comparison of methods of sizing stand-alone hybrid systems, these methods are as follows: Simulink optimization model in MATLAB, use of equations, HOGA and HOMER software. The results shown by all the different methods all lied within acceptable ranges, but the more expensive systems were given by HOGA and HOMER models. Also, [32], made a comparison between Lindo simulation software and HOMER in modelling Electrical renewable energy systems with the aim to meet the load requirement of Jaunpur block of Uttaranchal state of India. 
From the results obtained, it indicated that HOMER presented systems with the higher cost of energy, hence they concluded that HOMER was a more extensive software as it took into consideration the individual costs of components such as batteries, converters, grid energy cost were as Lindo software only took into consideration the cost of components directly related with the renewable energy systems only.

[33], stated that there are many environmental influences resulting from the use of hybrid systems. He also stated that utilizing renewables systems especially hybrid systems has the capacity to reduce the emission of greenhouse gases and it will serve and preserve from extinction the convention and expendable sources of energy. He was also to estimate to a certain amount of accuracy the cost of energy saved and the percentage of $\mathrm{CO}_{2}$ saved annually.

In this study, different HES configurations are modeled using both the meteorological and surveyed load data collected from a typical remotely located village in Akwa Ibom State of Nigeria with the aim of determining most suitable option that will optimally meet their energy demand economically while taken into consideration the environmental impact.

\subsection{WIND ENERGY POTENTIAL IN NIGERIA}

There are many researches highlighting the potential of wind energy resource in Nigeria. [34], carried out an analysis gathering wind speed data from up to 30 stations in Nigeria, and he concluded the average wind speed lies between 1.5 to $4.1 \mathrm{~m} / \mathrm{s}$ per year and $5.7-22.5 \mathrm{~W} / \mathrm{m} 2$ of power flux density. [35] gathered also a 10-year wind data from the year 19791988, he studied higher winds and surface winds and he also considered maximum guts. According to [36] in their study on the cost benefits and statistical analyses of the potential of wind energy of a site in Maiduguri, he made his simulations using Weibull statistics and he carried out his analysis using a Ten years data of wind speed gathered between 1995-2004. In was discovered by [37] that the greatest wind speed is obtained in the region of high altitude and elevation above sea level also topographies in the middle the ware upland and the boundaries to the north of Nigeria has high potential for the harvest of wind energy. He made a discovery that the wind speed in the north was the highest and was about $4.0-7.5 \mathrm{~m} / \mathrm{s}$ while that of the south was about 3.0 to $3.5 \mathrm{~m} / \mathrm{s}$ at the elevation of $10 \mathrm{~m}$.

\subsection{SOLAR ENERGY POTENTIAL IN NIGERIA}

In terms of unlimited capacity of generation, the most favourable source of renewable energy. The energy radiated from the sun per second is equated to $3.8 \times 10^{23} \mathrm{~kW}$. The majority of this transmitted energy reaches the earth atmosphere through the process of electromagnetic radiation and this energy at the point of entering the earth's atmosphere is approximately $1.5 \mathrm{kw} / \mathrm{m}^{2}$.

The total solar energy reception of Nigeria is about $5.08 \times$ $10^{12} \mathrm{kWh}$ daily and if a solar generator (PV or other solar technologies) which has an efficiency of as low as 5\% efficiency is used to cover just one percent of nation's surface, a total of $2.54 \times 10^{6} \mathrm{MWh}$ of electrical energy is obtainable [38]. The equivalent of this energy can also be derived from 4.66 million barrels of oil daily. Typical application of solar energy could either be used directly or converted into electrical energy for carrying the following such as heating, cooking, distillation, refrigeration and air condition and other industrial applications.

\subsection{RESEARCH METHODS}

\subsection{Description of the Site}

Ikot Inyang is a rural community or village (a remote area) in Ikot Ekpene Local Government Area in Akwa Ibom State, South-South Nigeria. It is located at $5^{\circ} 9^{\prime} 36.8604^{\prime \prime} \mathrm{N}$ and 741'13.9416" East (Latitude: 5.160239, Longitude: 7.687206). It has a population of about 450 residents which majority are indigenes and the rest are mostly student. The data utilized for the simulation which includes the wind speed and the solar irradiation were obtained or downloaded using HOMER software and this data were gathered for over a period of twenty-two (22) years by the National Aeronautical and Space Administration (NASA) whose headquarters is at the United States.

\subsection{FACTORS FOR THE SELECTION OF THE MOST OPTIMUM HYBRID SYSTEM}

The determination of the most optimum solution of the hybrid energy will be based on set criteria and the utilization of different yardstick with which the optimum system should score high when judged based on the all the criteria. This includes: The Net Present Cost, Levelized cost of Energy, Carbon Emission Intensity as well as the Renewable Fraction (RF).

\subsubsection{NET PRESENT COST}

Net Present Cost is the summation of the cost of the system throughout life cycle of the system. The life cycle cost of the system includes the cost of equipment purchase and setting up (capital cost), replacement cost, cost of operation, fuel cost stands, maintenance cost, tax as well as cost of fulfilling community developmental services. When the most important consideration is cost reduction, the energy system result with the lowest Net Present Cost is selected.

$N P C=C_{0}+C_{r}+\sum_{t=1}^{N} \frac{C(t)}{(1=i n) t}-R$

Where $\mathrm{C}_{0}=$ initial capital, $\mathrm{C}_{\mathrm{r}}$ for the replacement cost when $\mathrm{t}=0, \mathrm{R}=$ the Residual value at the time, $\mathrm{t}=0, \mathrm{C}(\mathrm{t})$ is the cost per annum which is a function of time and is given as:

$C(t)=C_{m o}(t)+C_{f}(t)$

Where $\mathrm{C}_{\mathrm{mo}}$ is the cost of maintenance and operation and $\mathrm{C}_{\mathrm{f}}(\mathrm{t})$ is the fuel cost in t numbers of years. 


$$
\begin{aligned}
& C_{m o}=C_{m o}, 1 \sum_{t=1}^{N} \frac{1}{(1+i n)^{t}}=C_{m o}, t \times P R_{L} \\
& C_{f}=C_{f}, 1 \sum_{t}^{N} \frac{1}{(1+i n)^{t}}=c_{f}, 1 * P R_{L} \\
& P R_{L}=\sum_{t}^{N} \frac{1}{(1+i)^{t}}=\frac{(1+i n)^{N}-1}{i(1+i n)^{N}}=\frac{1}{C_{R F}}
\end{aligned}
$$

Where $\mathrm{N}$ is the total number of years of the project otherwise known as the project lifetime and "in" represents the interest rates annually respectively.

Overall annualized cost $\left(\mathrm{A}_{\mathrm{y}}\right)$ which is given as sum total of the cost associated with the project as well as other cost as stated in equation (ii).

$A_{y}=N P C \times C_{R F}$

Where $\mathrm{C}_{\mathrm{RF}}$ is the capital recovery cost and $\mathrm{A}_{\mathrm{y}}$ represents the overall annualized cost.

As inflation values are not indicated in the analysis, the expenses per year remains the same year after year, as there is no situation like that, hence, this analysis is theoretical and not factual. As a result of that we can rewrite the equation as follows

$N P C=C_{0}+C_{r}+C_{m o}+C_{f}-R$

\subsubsection{LEVELIZED COST OF ENERGY}

This can be defined as the mean cost of per kilowatt-hour $(\mathrm{kWh})$ of usable electrical energy generated by a system during the period of useful life. This is also the minimum price the energy consumer is expected to pay for the supply and utilization of a kilowatt-hour of electrical energy.

To calculate the Levelized Cost of Energy, there has to be a division of the cost of electrical energy produced by the system per year (annualized cost) by the actual useful energy which is generated by the system during the same time frame.

$L C O E=\frac{A_{n c}}{T_{L}}$

Where LCOE is the levelized cost of energy, $\mathrm{Anc}_{\mathrm{nc}}$ is the total cost of electric energy produced per year (also known as the Annualized cost) and $T_{L}$ total electrical load supplied by the energy system annually.

\subsubsection{CARBON EMISSION INTENSITY}

This is the amount of carbon emitted by the energy system in the process of generating electrical energy. This is also the percentage of carbon produced by an energy system.
Mathematical, Carbon Emission Intensity $C_{i}$ of any energy system is given as

$C_{i}=\sum_{1}^{n} E n \times P n$

Where En is the potential carbon emission of each energy generating source per kilowatt-hour of energy produced by a single source and Pn is the amount of energy generated by each different type of generating source.

\subsubsection{RENEWABLE FRACTION}

Renewable fraction is the comparison of the total amount energy produced by a renewable energy sources with the total amount of energy produced by entire hybrid energy system. Renewable fraction is needed as high as possible but also considering the consequences it has on the Net Present Cost of the energy system, this is due to the fact that at most times, the load demand is expected to be met in totality by a renewable source(s) of energy. The Renewable Fraction of a hybrid energy system is given as:

$R F(\%)=\left[1-\frac{\sum_{1}^{i} P_{d} i}{\sum_{1}^{i} P_{r} i}\right] \times 100$

Where $\mathrm{P}_{\mathrm{d}}$ is the power generated by the fossil generator (e.g. diesel generator) and $\mathrm{Pr}_{\mathrm{r}}$ is the power produced by the renewable energy sources (e.g. Wind and solar PV).

\subsection{ENERGY DEMAND ESTIMATION AND HOURLY PROFILING OF IKOT INYANG RURAL COMMUNITY}

This profiling was carried out and results were based on the oral interview performed on the indigenes and residents of the community. In this study, loads will be classified into social infrastructural loads (SL) and domestic loads (DL). A total of 75 residential buildings has been profiled. To estimate the loads, we make an assumption that the loads of all residential buildings are similar and hence energy requirement are equal as well. One building is used to carry out all the domestic load estimates and it is purely based on the necessities of the people in the area, obtained during the oral interviews performed. Some loads have been removed due to the fact that very few residential buildings have it like air-conditioner, heat extractors, washing machine etc. Electrical appliances were scheduled and profiled according to their use and according to the time of use with a 24hours time frame. For residential buildings the loads were divided to 2 loads with predictable patterns of utilization and loads whose patterns of utilization are not predictable but based on individual's priorities and preferences.

There is also a secondary school, a primary health care centre and four (4) shops the loads from these locations forms the social infrastructural load in the area. Load estimation will be made according the devices and appliances utilized. The unpredictable loads are loads which is assumed to run continuously throughout the 24 hour period 
and consume a consistent about of energy all through the day, however it can be turned off based on individual's preference and not on any predictable pattern. Predictable loads are those that are turned off when their work is done and it doesn't run throughout the day (24hours). When carrying out and estimation of load (energy) demand of the shops only a shop will be considered and the value of the estimation will be multiplied across the four shops, as assumption is made that all shops utilizes similar equipment and hence consumes the same quantity of energy and 6 shops were counted and another additional 2 were forecasted. All infrastructural loads are considered predictable loads as the operation time can be estimated without much error. Estimation and scheduling are done throughout the 24hours period. The unpredictable load is assumed to run continually and the predictable load are scheduled and profiled during off peak periods. 6 water pumps were seen in the community and an addition four for future loads is added making it 10 . Due to individual preference, a diversity factor of 0.7 is applied throughout all loads connected to the system. From figure 3.1 , it can be seen that peak period occurs at 14.00 to $15.00(2 \mathrm{pm}$ to $3 \mathrm{pm})$ with total system load as high as $32.55 \mathrm{~kW}$ when the diversity factor is applied. The peak $\mathrm{kW}$ demand is given as $58.62 \mathrm{~kW}$, the mean load demand on the system per hour is given as $27.94 \mathrm{~kW}$, while the annualized scaled average load requirement is given as $670.65 \mathrm{kWh}$ per day

\subsection{SYSTEM DESIGN}

Table 3.2.: Optimal Hybrid Energy system design plan for Ikot Inyang Rural community

\begin{tabular}{|c|c|c|c|c|}
\hline Plan & Battery & Diesel & Solar PV & $\begin{array}{c}\text { Wind } \\
\text { turbine }\end{array}$ \\
\hline A & $\times$ & $\checkmark$ & $\times$ & $\times$ \\
\hline B & $\checkmark$ & $\checkmark$ & $\times$ & $\times$ \\
\hline C & $\checkmark$ & $\times$ & $\checkmark$ & $\times$ \\
\hline D & $\checkmark$ & $\times$ & $\times$ & $\checkmark$ \\
\hline E & $\checkmark$ & $\checkmark$ & $\checkmark$ & $\times$ \\
\hline F & $\checkmark$ & $\checkmark$ & $\times$ & $\checkmark$ \\
\hline G & $\checkmark$ & $\times$ & $\checkmark$ & $\checkmark$ \\
\hline H & $\checkmark$ & $\checkmark$ & $\checkmark$ & $\checkmark$ \\
\hline
\end{tabular}

The different plans that will be used for discussions and conclusions will be drawn from here. Figure 3.3. will be used to make comparison to discover which of the plans provides a more optimal, energy efficient and cost beneficial system. The criteria that will be used to determine the most efficient and optimal system is as discussed above which includes the Net Present Cost, Renewable fraction, Carbon Emission Intensity and Levelized cost of energy.

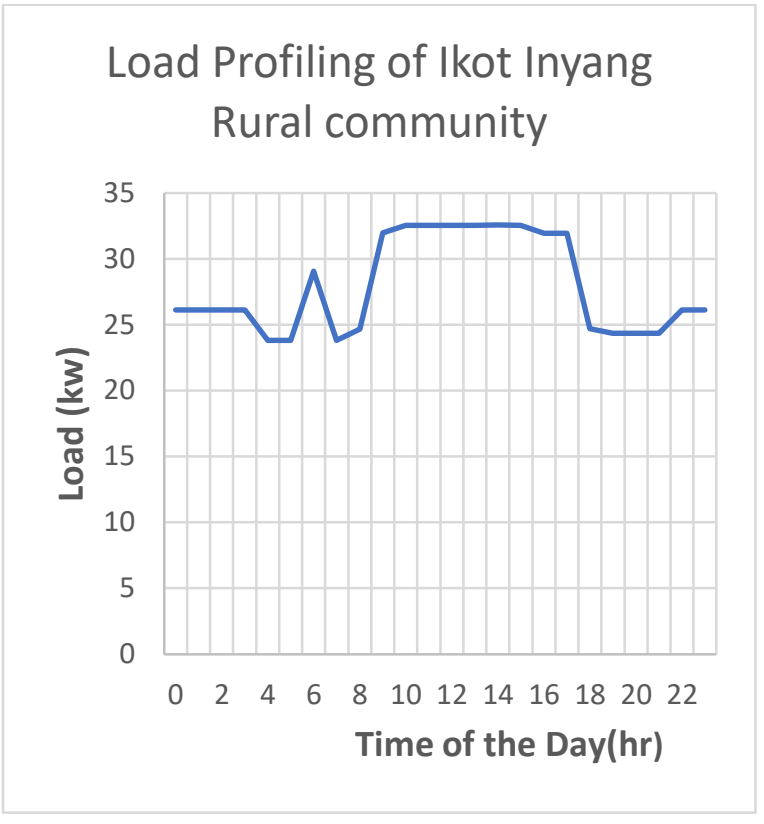

Figure 3.1 Hourly load scheduling for Ikot Inyang rural community

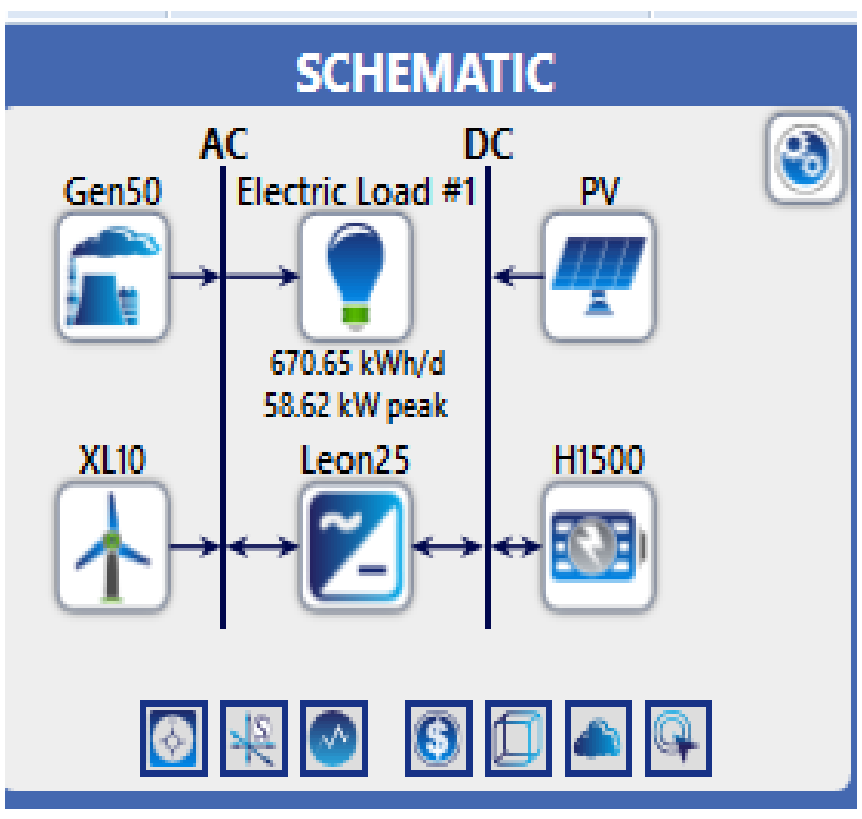

Figure 3.2.: Design schematic of optimal hybrid energy system in Ikot Inyang rural community

\subsection{WIND ENERGY DATA}

The wind energy resource data is downloaded directly from HOMER software, and the data is downloaded from NASA 
(The National Aeronautics and Space Administration) data base.

Often times, wind speed data obtained at certain heights are not similar to the wind speed obtained at a certain hub height when making use of wind turbines used for commercial purposes worldwide. Because of this factor, definition of windspeed from the height of installation (Hub height) is very important in order to obtain a more accurate data. Power law equation gives the solution for obtaining wind speed at a specific wind hub. This wind speed will alter the wind speed obtained from the National Aeronautical and Space Administration (NASA) database and the modified wind speed data will be entered into HOMER to carry out the simulations in order to obtained more accurate data with consideration to the hub height. The hub height has to high especially when the installation is onshore and in an open area in order to avoid obstructions of wind paths resulting in utilization of maximum wind speed, hence maximum power is obtained that is potential available in that area.

$W s_{2}=W s_{1}\left(\frac{d_{2}}{d_{1}}\right)^{m}$

Here $\mathrm{Ws}_{2}$ is the wind speed at the height (distance of the ground) $d_{2}$ and $W_{s}$ is the wind velocity at the height $d_{1}$ also $\mathrm{m}$ is called the shear exponent and it depends on the stability of the atmosphere on the surface where the components are mounted. The shear component factor is site-specific and has a rating between $0.00001-3 \mathrm{~m}$. Ikot Inyang rural community is located in tropical rainforest vegetation and hence the shear component was assumed to be 0.1 which was taken into consideration during the calculation to obtain the wind speed used for the simulation. The mean wind speed data is obtained monthly from the National Aeronautical and Space Administration (NASA) database for the period of 10years, and the anemometer height was $10 \mathrm{~m}$. This information was used to calculate the windspeed of the turbine at the specific height. The Hub height for Ikot Inyang was chosen by design to be $80 \mathrm{~m}$.

Applying power equation to the wind speed we have:

$W s_{2}=W s_{1}\left(\frac{80}{10}\right)^{0.1}=W s_{1}(8)^{0.1}=W s_{1} \times 1.23$

$W s_{2}=W s_{1} \times 1.23$

Table 3.3.: Wind speed data for Ikot Inyang Rural Community

\begin{tabular}{|c|c|c|}
\hline Months of the Year & WS $_{\mathbf{1}}$ & WS $_{\mathbf{2}}$ \\
\hline January & 2.750 & 3.395 \\
\hline February & 2.970 & 3.656 \\
\hline March & 2.710 & 3.336 \\
\hline April & 2.390 & 2.942 \\
\hline May & 2.230 & 2.745 \\
\hline June & 2.810 & 3.459 \\
\hline
\end{tabular}

\begin{tabular}{|c|c|c|}
\hline July & 3.210 & 3.952 \\
\hline August & 3.370 & 4.148 \\
\hline September & 2.960 & 3.644 \\
\hline October & 2.350 & 2.893 \\
\hline November & 2.250 & 2.770 \\
\hline December & 2.400 & 2.954 \\
\hline
\end{tabular}

$\mathrm{WS}_{2}=$ Calculated wind speed at the hub height of $80 \mathrm{~m}, \mathrm{WS}_{1}$ $=$ Wind speed data from NASA. The Average annual wind speed is 3.32. The lowest wind speed was in may which was $2.745 \mathrm{~m} / \mathrm{s}$. The calculated wind speed data is used for the simulation of the work.

\subsection{SOLAR ENERGY RESOURCES}

The data solar irradiation resources gathered here is downloaded using HOMER which was collected from the National Aeronautical and Space Administration (NASA) database. The scaled annual mean solar irradiation of Ikot Inyang rural community was $4.71 \mathrm{kWh} / \mathrm{m}^{2} /$ day. The month with the highest solar irradiation is February which is 5.59 $\mathrm{kWh} / \mathrm{m}^{2} /$ day and the lowest solar irradiation occurs in Augusts which is $3.77 \mathrm{kWh} / \mathrm{m}^{2} /$ day.

Table 3.4.: Solar radiation data for Ikot Inyang Rural community

\begin{tabular}{|c|c|c|}
\hline Months & $\begin{array}{c}\text { Clearness } \\
\text { Index }\end{array}$ & $\begin{array}{c}\text { Solar Radiation } \\
\left(\mathrm{kWh} / \mathrm{m}^{2} / \text { day }\right)\end{array}$ \\
\hline January & 0.583 & 5.530 \\
\hline February & 0.559 & 5.590 \\
\hline March & 0.511 & 5.320 \\
\hline April & 0.490 & 5.090 \\
\hline May & 0.469 & 4.720 \\
\hline June & 0.438 & 4.310 \\
\hline July & 0.388 & 3.850 \\
\hline August & 0.369 & 3.770 \\
\hline September & 0.381 & 3.940 \\
\hline October & 0.425 & 4.270 \\
\hline November & 0.507 & 4.840 \\
\hline December & 0.570 & 5.290 \\
\hline
\end{tabular}

\subsection{SIZING/MODELLING OF $\quad$ SYSTEM COMPONENTS}

In order to accurately size components, there has to correctly estimate the load/energy requirement of the community. The energy requirement of Ikot Inyang community has been accurately stated to be $670.65 \mathrm{Kwh} /$ day with the peak load of the system at $58.62 \mathrm{Kw}$.

\subsubsection{SIZING OF THE PHOTOVOLTAIC SYSTEM}

The system peak load of the system at $58.62 \mathrm{Kw}$ which is being considered for the design of the photovoltaic energy 
system. HOMER optimizer is used to obtain the most economic and optimal system. HOMER will specify the solar model sizes as well as quantity needed to produce the meet the required energy demand. In the solar PV model, there is a direct proportionality between the direct incident solar radiation and the output power from the solar model. The cost of solar panel ranges from $\$ 2.5$ to $\$ 4.5$ per watt depending on quality, hence the capital cost per Kilowatt is approximately $\$ 2500$.

Table 3.5: Solar PV design variables (Inputs) considerations

\begin{tabular}{|c|c|c|c|}
\hline $\begin{array}{c}\text { INPUT } \\
\text { TYPE }\end{array}$ & \multirow[t]{2}{*}{$\begin{array}{c}\text { VARIABLE } \\
\text { S }\end{array}$} & \multirow[t]{2}{*}{$\begin{array}{c}\text { VALU } \\
\mathbf{E}\end{array}$} & \multirow[t]{2}{*}{ UNIT } \\
\hline \multirow[t]{8}{*}{$\begin{array}{c}\text { TECHNICA } \\
\text { L }\end{array}$} & & & \\
\hline & $\begin{array}{l}\text { Panel Tilt } \\
\text { angle }\end{array}$ & 0 & Degree \\
\hline & $\begin{array}{l}\text { Azimuth } \\
\text { angle }\end{array}$ & 0 & $\begin{array}{l}\text { Degree } \\
\text { (W of S) }\end{array}$ \\
\hline & $\begin{array}{c}\text { Derating } \\
\text { factor }\end{array}$ & 95 & $\begin{array}{c}\text { Percentag } \\
\text { e }(\%)\end{array}$ \\
\hline & $\begin{array}{c}\text { Ground } \\
\text { reflectance }\end{array}$ & 20 & $\begin{array}{c}\text { Percentag } \\
\text { e }(\%)\end{array}$ \\
\hline & $\begin{array}{c}\text { Solar tracking } \\
\text { system }\end{array}$ & Nil & Nil \\
\hline & Lifetime & 25 & Years \\
\hline & $\begin{array}{c}\text { Temperature } \\
\text { coefficient }\end{array}$ & 0.5 & $\% /{ }^{0} \mathrm{C}$ \\
\hline \multirow[t]{3}{*}{ COST } & Capital cost & 2,500 & $\$ / \mathrm{Kw}$ \\
\hline & $\begin{array}{c}\text { Replacement } \\
\text { cost }\end{array}$ & 2,500 & $\$ / \mathrm{Kw}$ \\
\hline & $\begin{array}{c}\text { Operation } \\
\text { and } \\
\text { maintenance } \\
\text { cost }\end{array}$ & 25 & \$/year \\
\hline
\end{tabular}

The specific solar model has not been specified because the installation engineer can choose to purchase from a different manufacturer. The capital and replacement cost given in table 3.7 includes the cost of purchase, cost of transportation, cost of labour and other associated cost during installation of the solar model.

\subsubsection{SIZING OF BATTERY SYSTEM}

In order accurately estimate battery size, HOMER implements the following sets of equations by determining the excess energy the Hybrid Energy System generates.

$S_{b s}=\frac{\sum_{i=0}^{8760} E_{\chi}(t) \times C_{e f}}{V_{l}}$

Where $E_{x}$ is the excess electrical energy generated that is evacuated to be stored by the storage system (battery), $\mathrm{C}_{\mathrm{ef}}$ is the charging efficiency and $\mathrm{V}_{l}$ is the voltage level of the battery.
The excess electrical energy generated and evacuated to be stored $\left(\mathrm{E}_{\mathrm{x}}\right)$ can also be written as:

$E_{x}(t)=\sum_{i=0}^{8760} E_{S}(t)-E_{u}(t)$

Where $E_{s}$ is the sum total of the electrical energy generated by all the renewable sources combines (i.e. the solar PV and Wind turbine) per hour and $\mathrm{E}_{\mathrm{f}}$ is the total functional electrical energy utilized per hour. In circumstances where the total generated electrical energy from the renewable sources in the energy system is exceed the energy consumed by the system connected loads, the remainder of the energy will be stored in the battery. Likewise, when the energy generated by the renewable energy systems is less than the system connected load at any instance of time, the battery will be discharged to meet load requirement or the diesel backup generator will be dispatched to meet the required load.

In order to determine the optimal battery size, HOMER optimizer is utilized during the simulation, the battery sizing and quantity can be reduced or increase in order to obtain the most technically optimal and economically feasible system. Excess electrical energy generated is determined at the end of the simulation and is carefully detailed in the results of the optimization. Hoppecke $12 \mathrm{OPzS} 1500$ is the energy storage system used for the simulation. Hoppecke is a vented, lead acid, tubular-plate and deep-cycle battery.

Table 3.6: Storage system design variable (Inputs) considerations

\begin{tabular}{|c|c|c|c|}
\hline \multirow{2}{*}{$\begin{array}{l}\text { INPUT TYPE } \\
\text { TECHNICAL }\end{array}$} & \multirow[t]{2}{*}{ VARIABLES } & \multirow[t]{2}{*}{ VALUE } & \multirow[t]{2}{*}{ UNIT } \\
\hline & & & \\
\hline & Battery model & $\begin{array}{c}\text { Hoppecke } \\
12 \mathrm{OPzS} \\
1500\end{array}$ & Nil \\
\hline & $\begin{array}{l}\text { Nominal } \\
\text { Capacity }\end{array}$ & 3.59 & Kwh \\
\hline & $\begin{array}{l}\text { Nominal } \\
\text { Voltage }\end{array}$ & 2 & $\begin{array}{l}\text { Volts } \\
\text { (v) }\end{array}$ \\
\hline & $\begin{array}{l}\text { Maximum } \\
\text { charge rate }\end{array}$ & 1 & $\mathrm{~A} / \mathrm{Ah}$ \\
\hline & Capacity ratio & 0.317 & Nil \\
\hline & Float life & 10 & Years \\
\hline & $\begin{array}{c}\text { Minimum state } \\
\text { of charge }\end{array}$ & 40 & $\%$ \\
\hline \multirow[t]{3}{*}{ COST } & Capital cost & 400 & $\$ / \mathrm{Kw}$ \\
\hline & $\begin{array}{c}\text { Replacement } \\
\text { cost }\end{array}$ & 350 & $\$ / \mathrm{Kw}$ \\
\hline & $\begin{array}{l}\text { Operation and } \\
\text { maintenance } \\
\text { cost }\end{array}$ & 15 & \$/year \\
\hline
\end{tabular}

\subsubsection{SIZING OF THE POWER CONVERTER}


In order to accurately determine the size of power converted needed, the error margin has to be applied and put into consideration. Therefore, to calculate the minimum size of the converter, taking into consideration equation (xvi), and assuming an error margin of $5 \%$ and a capacity factor of 0.9 .

$P_{m}=\frac{P_{l f}+E_{r}}{C f}$

Where $\mathrm{P}_{\mathrm{m}}$ is the overall power derived, $\mathrm{P}_{\text {If }}$ is the peak load factor and $\mathrm{C}_{\mathrm{f}}$ is the capacity factor.

Ikot Inyang community has a peak load of $58.62 \mathrm{Kw}$. Applying the error margin of $5 \%$ and the capacity factor of 0.9 , we have:

$\mathrm{P}_{\mathrm{c}}=\frac{58.62 \times 1.05}{0.9}=68.39 \approx 68.4 \mathrm{~kW}$

With our design, we make use of a $25 \mathrm{~kW}$ converter system based on availability, HOMER will optimize it and find the quantity required to meet the system load demand. The converter size is set at $\$ 400$ per kilowatt and it's meant to last for a minimum of 15 years. The converter model used Leonics MTP $-413 \mathrm{~F} 25 \mathrm{~kW}$. To carry out simulation is done by search space optimizer, with the sizes specified as $0 \mathrm{~kW}$, $25 \mathrm{~kW}$ and $50 \mathrm{~kW}$ respectively.

Table 3.7: Converter system design variable (Inputs) considerations

\begin{tabular}{|c|c|c|c|}
\hline INPUT TYPE & VARIABLES & VALUE & UNIT \\
\cline { 1 - 3 } TECHNICAL & & & \\
\cline { 2 - 4 } & $\begin{array}{c}\text { Converter } \\
\text { model }\end{array}$ & $\begin{array}{c}\text { Leonics } \\
\text { MTP }- \\
413 \mathrm{~F} \\
25 \mathrm{~kW}\end{array}$ & Nil \\
\cline { 2 - 4 } & Rated Power & 25 & $\mathrm{~kW}$ \\
\cline { 2 - 4 } & $\begin{array}{c}\text { Relative } \\
\text { capacity }\end{array}$ & 80 & $\%$ \\
\cline { 2 - 4 } & $\begin{array}{c}\text { Inverter } \\
\text { efficiency }\end{array}$ & 96 & $\%$ \\
\cline { 2 - 4 } & $\begin{array}{c}\text { Rectifier } \\
\text { efficiency }\end{array}$ & 94 & $\%$ \\
\cline { 2 - 4 } Lifetime & 15 & Years \\
\hline \multirow{7}{*}{ COST } & Capital cost & 400 & $\$ / \mathrm{Kw}$ \\
\cline { 2 - 4 } & $\begin{array}{c}\text { Replacement } \\
\text { cost }\end{array}$ & 350 & $\$ / \mathrm{kW}$ \\
\cline { 2 - 4 } & $\begin{array}{c}\text { Operation and } \\
\text { maintenance } \\
\text { cost }\end{array}$ & 15 & $\$ / \mathrm{year}$ \\
\hline
\end{tabular}

\subsubsection{SIZING OF DIESEL GENERATOR}

The diesel generator is used during period of peak demand or periods of low availability of renewable energy generation. The diesel generator is also used in period where the renewable energy sources of generation and the battery system are under either routine or corrective maintenance.

Ikot Inyang community has a peak load of $58.62 \mathrm{~kW}$. Applying the error margin of 5\% and the capacity factor of 0.9 , we have:

$\mathrm{P}_{\mathrm{d}}=\frac{58.62 \times 1.05}{0.9}=68.39 \approx 68.4 \mathrm{~kW}$

Where $P_{d}$ is the power generated from the diesel generator (in this case diesel) generator. A $75 \mathrm{~kW}$ and $50 \mathrm{~kW}$ diesel generator will be used for the initial design simulation, HOMER optimizer will choose the optimal solution considering other related factors. Hence the cost of the generator will depend on the size eventually chosen after simulation.

Table 3.8: Diesel generator design variables (inputs) consideration

\begin{tabular}{|c|c|c|c|}
\hline \multirow{2}{*}{$\begin{array}{l}\text { INPUT TYPE } \\
\text { TECHNICAL }\end{array}$} & \multirow[t]{2}{*}{ VARIABLES } & \multirow[t]{2}{*}{ VALUE } & \multirow[t]{2}{*}{ UNIT } \\
\hline & & & \\
\hline & $\begin{array}{c}\text { Generetor } \\
\text { model }\end{array}$ & $\begin{array}{c}\text { Generic } \\
\text { Generator }\end{array}$ & Nil \\
\hline & Fuel type & Diesel & Nil \\
\hline & $\begin{array}{c}\text { Operational } \\
\text { lifetime }\end{array}$ & 15,000 & Hours \\
\hline & $\begin{array}{l}\text { Minimum } \\
\text { efficiency }\end{array}$ & 85 & $\%$ \\
\hline & $\begin{array}{l}\text { Fuel curve } \\
\text { gradient }\end{array}$ & 0.33 & $\begin{array}{c}1 / \mathrm{h} / \mathrm{kW} \\
\text { rated }\end{array}$ \\
\hline & $\begin{array}{c}\text { Fuel curve } \\
\text { intercept }\end{array}$ & 0.05 & $\begin{array}{c}1 / \mathrm{h} / \mathrm{kW} \\
\text { rated }\end{array}$ \\
\hline & $\begin{array}{c}\text { Minimum load } \\
\text { ratio }\end{array}$ & 30 & $\%$ \\
\hline \multirow[t]{4}{*}{ COST } & Capital cost & 300 & $\$ / \mathrm{kW}$ \\
\hline & $\begin{array}{l}\text { Replacement } \\
\text { cost }\end{array}$ & 300 & $\$ / \mathrm{kW}$ \\
\hline & $\begin{array}{c}\text { Operation and } \\
\text { maintenance } \\
\text { cost }\end{array}$ & 0.3 & \$/hour \\
\hline & Fuel cost & 0.65 & $\$$ \\
\hline
\end{tabular}

\subsubsection{METHOD FOR DISPATCHING THE DIESEL GENERATOR}

The determining factors for the diesel generator dispatch plan (strategy) includes the following:

i. Amount of renewable energy resources available

ii. Size/capacity of the renewable energy generators available 
iii. Size/capacity of energy storage (battery) system

iv. Price of diesel (fuel)

v. Size of the diesel generator

vi. Cost of maintenance and operation of the diesel generator

\subsubsection{SIZING OF WIND TURBINE}

To accurately determine the size of wind turbine, it necessary to take into consideration several factors that are different for every site such as minimum and maximum wind speed and also know the range in which different wind turbine operates accordingly.

To adequately size the wind turbine, the HOMER simulation optimizer is used. The wind turbine is the Bergey Excel 10 with the generation capacity of $10 \mathrm{~kW}$. The capital and replacement cost of Bergey Excel 10 is $\$ 25,000$ while it's operational and maintenance cost is set at $\$ 50.00 /$ year.

\subsection{RESULTS AND ANALYSIS OF RESULTS}

The result is also summarized based on the design plan we have in table 3.3 , is clearly given in table 4.1 . This design plan result does not follow the alphabetical order but it is arranged the order of the most optimal system based on the least Net Present Cost.

Table 4.1: Showing the NPC, COE and RF of design plan A $-\mathrm{H}$ in USD

\begin{tabular}{|c|c|c|c|c|c|}
\hline PLANS & $\begin{array}{c}\text { Dis } \\
\text { patch }\end{array}$ & $\begin{array}{c}\text { COE } \\
(\$)\end{array}$ & $\begin{array}{c}\text { NPC } \\
(\$)\end{array}$ & $\begin{array}{c}\text { Ren } \\
\text { Frac } \\
(\%)\end{array}$ & Combinations \\
\hline H & LF & 0.228 & $1.07 \mathrm{M}$ & 84.8 & D+W+S+B \\
\hline E & LF & 0.234 & $1.09 \mathrm{M}$ & 80.6 & D+S+B \\
\hline F & CC & 0.285 & $1.33 \mathrm{M}$ & 28.5 & \\
\hline & & & & & S+W+D \\
C & CC & 0.305 & $1.42 \mathrm{M}$ & 16.6 & \\
\hline & & & & & D+B \\
B & $\mathrm{CC}$ & 0.308 & $1.43 \mathrm{M}$ & 0 & \\
\hline & & & & & S+W+B \\
\hline $\mathrm{G}$ & $\mathrm{CC}$ & 0.342 & $1.60 \mathrm{M}$ & 100 & \\
\hline & & & & & \\
\hline
\end{tabular}

Table 3.9: Wind turbine design variable (input) consideration

\begin{tabular}{|l|l|l|l|}
\hline INPUT TYPE & VARIABLES & VALUE & UNIT \\
\cline { 1 - 3 } TECHNICAL & & & \\
\cline { 2 - 4 } & Turbine model & $\begin{array}{l}\text { Bergey } \\
\text { Excel } 10\end{array}$ & Nil \\
\cline { 2 - 4 } & Starting wind speed & 3 & $\mathrm{~m} / \mathrm{s}$ \\
\cline { 2 - 4 } & $\begin{array}{l}\text { Operational } \\
\text { lifetime }\end{array}$ & 25 & Years \\
\cline { 2 - 4 } & Cut-off wind speed & 25 & $\mathrm{~m} / \mathrm{s}$ \\
\cline { 2 - 4 } & Hub height & 80 & Metres \\
\cline { 2 - 4 } & Rating & 10 & $\mathrm{~kW}$ \\
\hline COST & Capital cost & 25,000 & $\$ / 10 \mathrm{~kW}$ \\
\cline { 2 - 4 } & Replacement cost & 25,000 & $\$ / 10 \mathrm{~kW}$ \\
\cline { 2 - 4 } & $\begin{array}{l}\text { Operation and } \\
\text { maintenance cost }\end{array}$ & 50 & $\begin{array}{l}\text { \$/year/tu } \\
\text { rbine }\end{array}$ \\
\hline
\end{tabular}

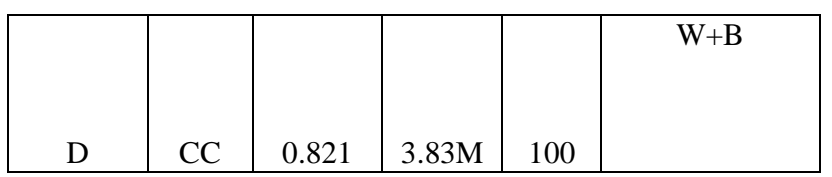

From the table 4.1 it shows clearly that the most optimal system design is the $\mathrm{H}$ design plan which comprises of a diesel generator, wind turbines, solar PV and the battery storage system which in our initial system design was in design plan $\mathrm{H}$.

\subsection{ANALYSIS OF THE MOST OPTIMUM SYSTEM FOR IKOT INYANG RURAL COMMUNITY}

The most optimum system is a hybrid energy system comprising of a diesel generator, wind turbine, solar PV system, converter and an energy storage system.

Table: 4.2: System architecture for the most optimal system for Ikot Inyang rural community

\begin{tabular}{|c|c|c|c|}
\hline Component & Type & Rating & $\begin{array}{c}\text { Quantity in } \\
\text { Use }\end{array}$ \\
\hline $\begin{array}{c}\text { Diesel } \\
\text { Generator }\end{array}$ & $\begin{array}{c}\text { Generic } \\
\text { Diesel } \\
\text { Generator }\end{array}$ & $50 \mathrm{~kW}$ & 1 \\
\hline $\begin{array}{l}\text { Wind } \\
\text { Turbine }\end{array}$ & $\begin{array}{c}\text { Bergey Excel } \\
10 \\
\end{array}$ & $10 \mathrm{~kW}$ & 5 \\
\hline Solar PV & $\begin{array}{l}\text { Generic flat } \\
\text { plate PV }\end{array}$ & $134 \mathrm{~kW}$ & Nil \\
\hline Converter & $\begin{array}{c}\text { Leonics MTP- } \\
413 \mathrm{~F} 25 \mathrm{~kW}\end{array}$ & $25 \mathrm{~kW}$ & 2 \\
\hline
\end{tabular}




\begin{tabular}{|c|c|c|c|}
\hline Battery & $\begin{array}{c}\text { Hoppecke 12 } \\
\text { OPzS 1500 }\end{array}$ & $3.59 \mathrm{~kW}$ & 204 strings \\
\hline $\begin{array}{c}\text { Dispatch } \\
\text { Method }\end{array}$ & $\begin{array}{c}\text { Homer Load } \\
\text { following }\end{array}$ & N/A & N/A \\
\hline
\end{tabular}

Table 4.2. shows the system architecture of the most optimal system, the system comprises of 1 diesel generator of any choice, 5 Bergey Excel 10 wind turbine which is a $10 \mathrm{~kW}$ wind turbine, $134 \mathrm{~kW}$ solar models of any type, 2 Leonics

From Fig. 4.1 and table 4.2 respectively, it is seen that the component with the highest capital cost is the Solar PV model which is $\$ 334,792$, followed by the wind turbine with the capital cost of $\$ 125,000$ and then the converter model with capital cost of $\$ 81,600$ in this category, the diesel generator has the lowest capital cost of $\$ 15,000$, but when it comes to replacement cost, the converter leads in this category with a total lifetime replacement cost of $\$ 103,555$ and it also has the highest salvage value of $-\$ 20,690$ nevertheless, the renewable energy equipment has no fuel requirement, hence under the cost of resources the renewable energy sources incur no cost at all but the cost of resource for the diesel generator although the operating lifetime is as much as $\$ 164,349$, all this cost accumulates and takes to total Net Present Cost of the system to $\$ 1.07 \mathrm{M}$. Table 4.3 also concludes the same which gives the annualized cost of the system for the total of 25 years lifetime.

\subsection{COST SUMMARY FOR SYSTEM H}

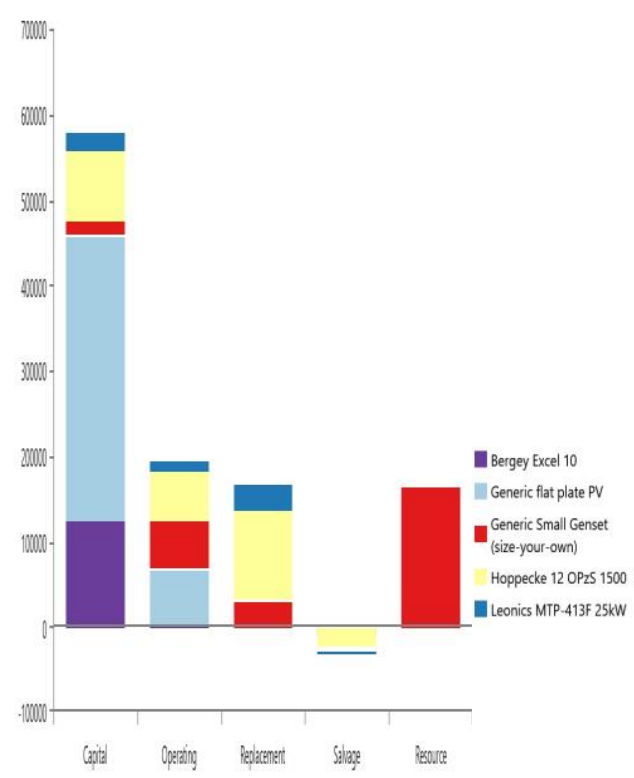

Figure 4.1: A chart of total cost summary for system $\mathrm{H}$

4.4 ELECTRICAL ENERGY RESULTS

Table 4.3: Excess electricity production and Unmet load

\begin{tabular}{|l|l|l|}
\hline Quantity & Value & Units \\
\hline Excess Electricity & 36,766 & $\mathrm{kWh} / \mathrm{yr}$ \\
\hline
\end{tabular}

MTP-413F 25kW converter and 204 strings of Hoppecke 12 OPzS 1500 battery system. The dispatch method of the most optimal system is the Load Following dispatch strategy, where the generator only supplies the load but the excess renewable energy available charges the battery respectively. This configuration and design make up the most optimal system, meet the required energy demand at the lowest Net Present Cost (NPC), with the highest renewable fraction thereby reducing fuel consumption and hence reduction in greenhouse gas emissions.

\begin{tabular}{|l|l|l|}
\hline $\begin{array}{l}\text { Unmet Electric } \\
\text { Load }\end{array}$ & 0 & $\mathrm{kWh} / \mathrm{yr}$ \\
\hline $\begin{array}{l}\text { Capacity } \\
\text { Shortage }\end{array}$ & 4.83 & $\mathrm{kWh} / \mathrm{yr}$ \\
\hline
\end{tabular}

Table 4.4: Production Summary of individual energy sources

\begin{tabular}{|l|l|l|}
\hline Component & $\begin{array}{l}\text { Production } \\
(\mathbf{k W h} / \mathbf{y r})\end{array}$ & Percent \\
\hline Generic flat plate PV & 220,000 & 72.7 \\
\hline Generic Small Genset (Diesel) & 37,291 & 12.3 \\
\hline Bergey Excel 10 Wind turbine & 45,457 & 15.0 \\
\hline Total & 302,748 & 100 \\
\hline
\end{tabular}

From table 4.3 and table 4.4 , it shows that all the system load were total met during the 25 years period proposed for the project, it shows that out of the $302,748 \mathrm{kWh}$ of energy generated by year by all the sources in the system, $36,766 \mathrm{kWh}$ of energy was excess energy generated per year. It also shows that $72.2 \%$ (220MWh) of all electrical energy generated per year was generated by the Solar PV this is because of the solar energy resource in the area, the wind turbine generated as much as $15 \%(45.5 \mathrm{MWh})$ per year but the least energy generated per year came from the diesel generator which contributed only $12.3 \%$ (7.3MWh) which gave a total of $303 \mathrm{MWh}$ of electrical energy per year. It can also be seen that the renewable energy sources produced a total of $87.2 \%$ of all electrical energy produced per year compared to $12.3 \%$ of electrical energy produced per year, this made the Load Following dispatch strategy the best method of utilizing the diesel generator.

\subsection{SYSTEM EMISSIONS RESULTS}




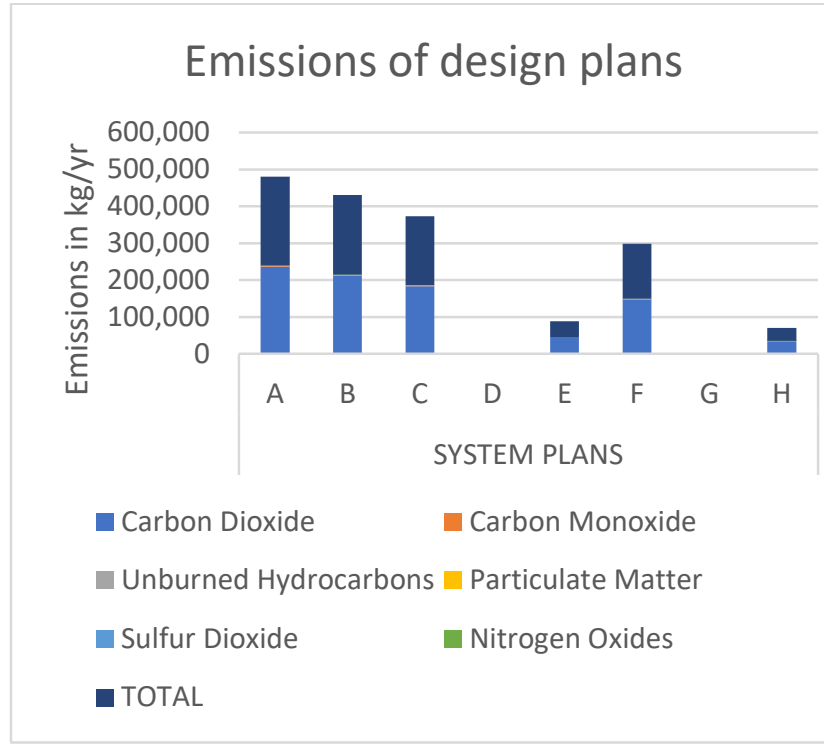

Fig. 4.2: A chart showing the net emission of each system plan per year

From figure 4.2, it is accurately shown that system Plan D (wind turbine + Battery) and G (Solar PV + wind turbine + battery) has no emissions because the sources of energy are total renewable, hence no emission, however these systems are not optimal because:

\section{i. High Net Present Cost \\ ii. Unmet Electrical load}

The unmet electrical load for system Plan D (wind turbine + Battery) and G (Solar PV + wind turbine + battery) are 109 $\mathrm{kWh} / \mathrm{yr}$ and $85.5 \mathrm{kWh} / \mathrm{yr}$ respective. The optimal system $\mathrm{H}$ is the system with a considerably low emissions, the lowest Net Present Cost and the Lowest LCOE. The systems with the most undesired A (Diesel only) and B (Diesel + Battery) which has the highest emissions.

\subsection{RENEWABLE FRACTIONS}

From Fig. 4.3, it seen that system Plan D (wind turbine + Battery) and G (Solar PV + wind turbine + battery) have the highest renewable fractions of $100 \%$ this is very favourable but it's high Net Present Cost and Unmet electrical load per years makes it economically and technically infeasible. Systems plan A (Diesel only) and B (Diesel + Battery) are not even considered has they have the lowest renewable fraction owing to the fact that they do not possess any renewable energy source. But the most optimal system is seen to be system plan H (Diesel + Wind turbine + Solar PV + Battery) which has one of the highest Renewable Fraction, one of the least emissions, the lowest Net present cost and the least Levelized cost of energy. Hence the most optimal system for Ikot Inyang rural community is the $\mathrm{H}$ system plan.

\section{RENEWABLE FRACTIONS OF SYSTEM PLANS}

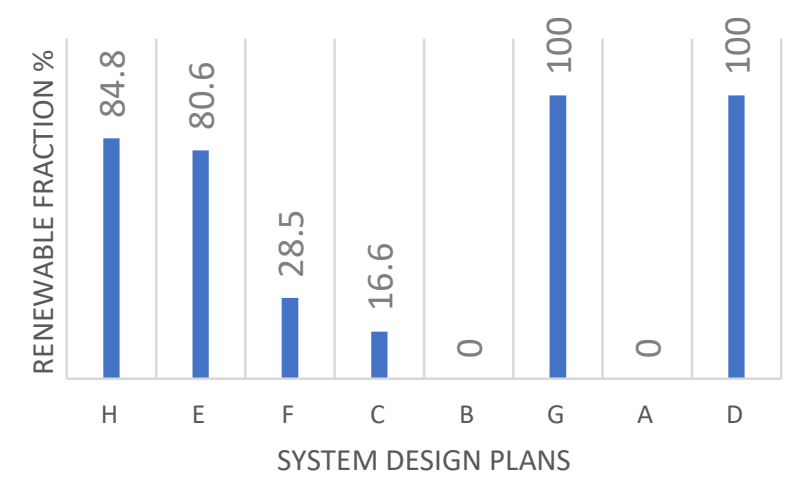

Fig 4.3: Renewable Fractions of different system design plans

\subsection{SUMMARY AND CONCLUSION}

Optimal hybrid energy systems are very crucial in modern life as the population growth is geometrical rates, dependence on bulk energy generation and grid supply cannot be sustained, hence the use of hybrid energy systems as a form of distributed generation must be encouraged and implemented. Many developed nations have employed this method in order to ensure that energy supply reaches every citizen including the local population in order to discourage rural-urban migration with lack of adequate supply of energy as an excuse. Hybrid renewable energy systems is meant to supply energy that is reliable, efficient, dependable and affordable for the consumption of the local population and also preserve the environment by reducing the greenhouse gases emission per kilowatt-hour of electrical energy generated. A hybrid renewable energy system was designed for Ikot Inyang rural community in Nigeria, was consisted of 50 houses, 8 shops, a school and a primary health care facility. The system designed was aimed at supply 24 hours constant power supply to the area for a 25 years period. The electrical energy supplies were to be cheap, reliable and green as possible. This project when implemented would improve and promote business growth in the area, increase the farming population, hence greater family yield, promote other socio-economic activity as well as improve the living conditions of the residence of Ikot Inyang. After system design, calculations and simulations, the most optimal system in terms of technical and economic considerations included a 50kW diesel generator, 5 Bergey Excel 10 wind turbine, $134 \mathrm{~kW}$ solar model, 204 strings of Hoppecke 12 OPzS 1500 battery and 2 Leonics MTP-413F 25kW converter. The dispatch method used for this system was the Load Following dispatch method. This method produced at least Net Present Cost of \$1.7M ( $\$ 349.36 \mathrm{M}$ ), Levelized Cost of Energy of $\$ 0.228$ ( $\$ 74.74$ ), considerably high 
Renewable Fraction of $84.7 \%$ and above all met all its proposed loads for the period of 25 years.

\subsection{REFERENCES}

[1] Rehman, S., Badeer, M.A. \& Al-Moallem, S.A., 2007. Cost of solar energy generated using pv panels. Renewable and sustainable Energy Reviews 11 (8): 1843-857.

[2] Elusakin J. E., Ajide O.O. \& Diji J. C., 2014; Challenges of sustaining off-grid power generation in Nigeria rural communities.

[3] Ajayi O O, Fagbenle R O, Katende J. Assessment of wind power potential and wind electricity generation using WECS of two sites in South West, Nigeria. International Journal of Energy Science, 2011, 1(2): 78-92

[4] Rohit S, 2013; Off grid Electricity Generation with Renewable Energy Technologies in India; an application of HOMER. Retrieved on the 3rd of May 2019.

[5] Dekker, J., Chowdhuryand, S. \& Chowdhury, S.P., 2010. Economic viability of pv/diesel hybrid power systems in different climatic zones in south africa IEEE Power and Energy Society General Meeting, Minneapolis, MN.

[6] Al-Badi, A.H. \& Bourdoucen, H., 2011. Study and design of hybrid diesel-wind standalone system for remote area in oman. International journal of Sustainable Energy 31 (2): 85-94.

[7] Jose', L., Bernal-Agustın, R. \& Dufo-Lo', P., 2009. Simulation and optimization of stand-alone hybrid renewable energy systems Renewable and Sustainable Energy Reviews 13: 2111-2118.

[8] Ohunakin OS. Energy utilization and renewable energy sources in Nigeria. J Eng Appl Sci 2010;5(2):171e7.

[9] García-Valverde, R., Miguel, C., Martínez-Béjar, R. \&. Urbina, A., 2009. Life cycle assessment study of a 4.2 kwp stand-alone photovoltaic. Solar Energy 83 (9): 1434-1445.

[10] Kumar US, Manoharan P. Economic analysis of hybrid power systems (PV/ diesel) in different climatic zones of Tamil Nadu. Energy Convers Manag 2014;80:469e76.

[11] Perez R, 2006. USA Today, Home Power Magazine. Retrieved: April 15, 2013.

[12]Erdinc O, Uzunoglu M. Optimum design of hybrid renewable energy systems: overview of different approaches. Renew Sustain Energy Rev 2012;16:141225.

[13] Bhattacharyya SC. Review of alternative methodologies for analysing off-grid electricity supply. Renew Sustain Energy Rev 2012;16:677-94.

[14] Kaundinya DP, Balachandra P, Ravindranath NH. Gridconnected versus stand-alone energy systems for decentralized power - a review of literature. Renew Sustain Energy Rev 2009;13:2041-50.

[15] Bajpai P, Dash V. Hybrid renewable energy systems for power generation in stand-alone applications: A review. Renew Sustain Energy Rev 2012;16:2926-39.
[16] Bernal-Agustín JL, Dufo-López R. Simulation and optimization of stand-alone hybrid renewable energy systems. Renew Sustain Energy Rev 2009;13:2111-8.

[17]Fathima AH, Palanisamy K. Optimization in microgrids with hybrid energy systems - a review. Renew Sustain Energy Rev 2015;45:431-46.

[18] Mahesh A, Sandhu KS. Hybrid wind/photovoltaic energy system developments: critical review and findings. Renew Sustain Energy Rev 2015;52:1135-47.

[19] Upadhyay S, Sharma MP. A review on configurations, control and sizing methodologies of hybrid energy systems. Renew Sustain Energy Rev 2014;38:47-63.

[20] Shivarama Krishna K, Sathish Kumar K. A review on hybrid renewable energy systems. Renew Sustain Energy Rev 2015;52:907-16.

[21] Dusabe, D., Munda, J.L. \& Jimoh, A.A., 2009. Rural village electrification in south africa: Role of energy efficient in off-grid pv/dg system. active.cput.ac.za/energy/past_paper.

[22] Anwari, M., Rashid, M.I.M., Muhyiddin, H.T.M. \& Ali, A.R.M., 2012. An evaluation of hybrid wind/diesel energy potential in pemanggil island malaysia IEEE Conference on Power Engineering and Renewable Energy, Bali, Indonesia 17-21.

[23] Seyed, J. \& Mohammad, F., 2011. Analysis of hybrid wind/fuel cell /battery/ diesel energy system under alaska condition. The 8th Electrical Engineering and Electronics, Computer, Telecommunications and University, Thailand, 917-920.

[24] Nfaha, E.M., Ngundamb, J.M. \& Tchindaa, R., 2007. Modelling of solar/diesel/battery hybrid power systems for far-north cameroon. Renewable Energy 32: 832844.

[25] Mekhilef, S. \& Chandrasegaran, D., Year. Assessment of off-shore wind farms in malaysia IEEE Region 10 conference (TENCON 2011), Bali, Indonesia, 13511355

[26] Barsoum, N.N. \& Vacent, P., 2007. Balancing cost, operation and performance in integrated hydrogen hybrid energy system First Asia International Conference on Modelling \& Simulation.

[27] Ashok, S. \& Balamurugan, P., 2007. Biomass gasifierbased hybrid energy system for rural areas IEEE Canada Electrical Power Conference, Canada.

[28] Rashayi, E. \& Chikuni, E., 2012. The poetential of grid connected photovotaic array in zimbabwe. IEEE Mediterranean Electrotechnical Conference. Yasmine, Hammamet.

[29] Sekgoele, K., Chowdhury, S.P. \& Chowdhury, S., 2011. Technical and economic assessment of power generation from landfill gas in south Africa. IEEE Power and Energy Society General Meeting. San Diego, CA, 1-8.

Environmental effects of energy policy in sicily:The role of renewable energy. Renewable and Sustainable Energy Reviews 11: 282-298.

[30] Nahari, A. \& Dashti, R., 2011. Technical and economic analysis of different micropowers in providing network load and optimal selection with real load analysis of a $20 \mathrm{kv} / 400 \mathrm{v}$ station in bushehr province of iran. The 
International Conference on Advanced Power System Automation and Protection. Beijing, China.

[31] Castañeda, M., Fernández, L.M., Sánchez, H., Cano, A. \& Jurado, F., 2012. Sizing methods for stand-alone hybrid systems based on renewable energies and hydrogen. IEEE Mediterranean Electrotechnical Conference (MELECON). Yasmine, Hammamet, Tunisia.

[32] Akella, A.K., Sharma, M.P. \& Saini, R.P., 2007. Optimum utilization of renewable energy sources in a remote area. Renewable and Sustainable Energy Reviews 11: 894-908.

[34] Adekoya L O, Adewale A A. Wind energy potential of Nigeria. Renewable Energy, 1992, 2(1): 35-39

[35] Fagbenle R O, Karayiannis T G. On the wind energy resources of Nigeria. International Journal of Energy Research, 1994, 18(5): 493-508

[36] Ngala G M, Alkali B, Aji M A. Viability of wind energy as a power generation source in Maiduguri, Borno state, Nigeria. Renewable Energy, 2007, 32(13): 2242-2246

[37] Ajayi O O. The potential for wind energy in Nigeria. Wind Engineering, 2008, 34(3): 303-311

[38] Chiemeka I. U and Chineke T. C (2009). Evaluating the global solar energy potential at Uturu, Nigeria, International Journal of Physical Sciences Vol. 4 (3), pp. 115-119 